\title{
Horticultural use of copper-based fungicides has not increased copper concentrations in sediments in the mid- and upper Yarra Valley
}

\author{
Adam M. Wightwick ${ }^{\text {a,b,c }}$, George Croatto ${ }^{\text {d }}$, Suzanne M. Reichman ${ }^{\text {f }}$, Neal W. Menzies ${ }^{\text {a,b }}$, \\ Vincent Pettigrove $^{\text {e,g }}$, Graeme Allinson ${ }^{\text {c,e* }}$
}

${ }^{\text {a }}$ The University of Queensland, School of Agriculture and Food Sciences, St Lucia, Queensland 4072, Australia

${ }^{\mathrm{b}}$ Co-operative Research Centre for Contamination Assessment and Remediation of the Environment (CRC CARE), Mawson Lakes, South Australia 5095, Australia

${ }^{c}$ Future Farming Systems Research, Department of Primary Industries, 2a Bellarine Highway, Queenscliff, Victoria 3225, Australia

${ }^{\mathrm{d}}$ Future Farming Systems Research, Department of Primary Industries, Ernest Jones Drive, Macleod, Victoria 3085, Australia

${ }^{\mathrm{e}}$ Centre for Aquatic Pollution Identification and Management (CAPIM), The University of Melbourne, Bio21 Institute, 30 Flemington Road, Parkville, Victoria 3010 Australia

${ }^{\mathrm{f}}$ RMIT University, School of Civil, Environmental and Chemical Engineering, GPO Box 2476, Melbourne, Victoria 3001, Australia

${ }^{\mathrm{g}}$ Melbourne Water, Research and Technology, PO Box 4342, Melbourne Vic 3001, Australia

* Corresponding author: Department of Primary Industries, PO BOX 114, Queenscliff, Victoria, Australia 3225; telephone: +61-3-52580111; Email: graeme.allinson@dpi.vic.gov.au 


\begin{abstract}
The use of $\mathrm{Cu}$-based fungicide can pose a risk to nearby surface water bodies due to the run-off of accumulated $\mathrm{Cu}$ from agricultural soils. In 2008, we conducted a reconnaissance survey of the presence and concentration of copper in sediments at 18 sites within the Yarra River catchment, an important horticultural production system in south-eastern Australia. Observed $\mathrm{Cu}$ concentrations in sediment samples from study sites (mean (95\% confidence interval) 12.0 (10.613.6) $\mathrm{mg} / \mathrm{kg}$ dry weight) were similar to the concentrations present in the samples from the reference sites (mean (95\% confidence interval) 12.0 (6.7-16.8) $\mathrm{mg} / \mathrm{kg}$ dry weight). The data on $\mathrm{Cu}$ and other metals in the sediments suggests that that there is unlikely to have been wide spread, diffuse, off-site transport of $\mathrm{Cu}$ from the soils of horticultural properties to nearby surface waterways in the Yarra River catchment, and that that observed sediment metal concentrations are unlikely to pose an ecological risk to sediment dwelling organisms at the study sites.
\end{abstract}

\title{
Keywords
}

Copper-based fungicides; catchment; horticulture; sediment; environmental risk 


\section{Introduction}

Copper-based fungicides, e.g. copper sulphate, copper oxychloride, copper hydroxide, are amongst the most widely used pesticides in vineyards and orchards. The regular use of Cu-based fungicides results in an accumulation of $\mathrm{Cu}$ in surface soils (Wightwick et al. 2010a). For instance, $\mathrm{Cu}$ concentrations in the surface soils of vineyards with histories of $\mathrm{Cu}$-based fungicide use have typically been reported to range from 130 to $1280 \mathrm{mg} / \mathrm{kg}$ in European vineyards, and from 24 to $159 \mathrm{mg} / \mathrm{kg}$ in Australian vineyards (Wightwick et al. 2008; Komárek et al. 2010). Applications of $\mathrm{Cu}$-based fungicides have been linked to reductions in microbial function and changes in the structure of microbial communities of vineyard and orchard soils (Ranjard et al. 2006; Diaz-Ravina et al. 2007; Wang et al. 2009; Fernández-Calviño et al. 2010). In addition to these more widely documented risks to soil organisms the use of $\mathrm{Cu}$-based fungicide can pose a risk to nearby surface water bodies due to the run-off of accumulated $\mathrm{Cu}$ from agricultural soils (Fernández-Calviño et al. 2008; Ribolzi et al. 2002). For instance, Bereswell et al (2012) reported that surface water sediment $\mathrm{Cu}$ concentrations can be in the same range as those actually measured in cultivated vineyard soils in the Palatinate wine-growing region of south-west Germany.

Copper is an essential micronutrient for most organisms. However, this metal has a rather limited range below which deficiency-induced disease results, and above which toxicity is observed e.g., herbage with less than $5 \mu \mathrm{g} / \mathrm{g}$ can lead to copper deficiency in sheep and cattle, but with greater than $10 \mu \mathrm{g} / \mathrm{g}$ toxicity will occur in sheep. Copper pollution can arise from mining and smelting, leaching from municipal waste disposal sites, or excess use of agrochemicals (Allinson et al. 2000). Sediments are known long-term sources of secondary metal contamination for aquatic organisms due to their capacity to sequester and subsequently release metals (Luoma and Rainbow 2008). For pelagic organisms, exposure is through metals released into the water column; for benthic organisms, exposure occurs via both the water column and pore water, and via direct contact and/or consumption of contaminated sediments. Consequently, sediments are a key compartment that has to be taken into account in aquatic ecosystem risk assessments.

Aquatic ecosystems rely on microbial communities for key ecosystem functions, such as nutrient cycling and litter decomposition, so any negative effects on sediment microbial communities caused by $\mathrm{Cu}$-based fungicides could have significant implications for the long-term fertility of aquatic systems. 
This reconnaissance survey examined the presence and concentration of copper in sediments at 18 sites within the Yarra Catchment, in south-eastern Australia. This study was undertaken as part of a broader study on the fate and potential ecological impacts of agricultural chemicals within the Yarra Catchment (Schäfer et al. 2011; Wightwick et al. 2012), in which sampling locations were selected to encompass a broad spatial spread of different land uses across the catchment (i.e. non-targeted sampling). In that context the sampling locations did not specifically incorporate areas of know point-source contamination due to $\mathrm{Cu}$-based fungicide use, but still allowed us to address the objective of this study, which was to generate new data on copper residues in aquatic ecosystems in this important horticultural production system.

\section{Materials and methods}

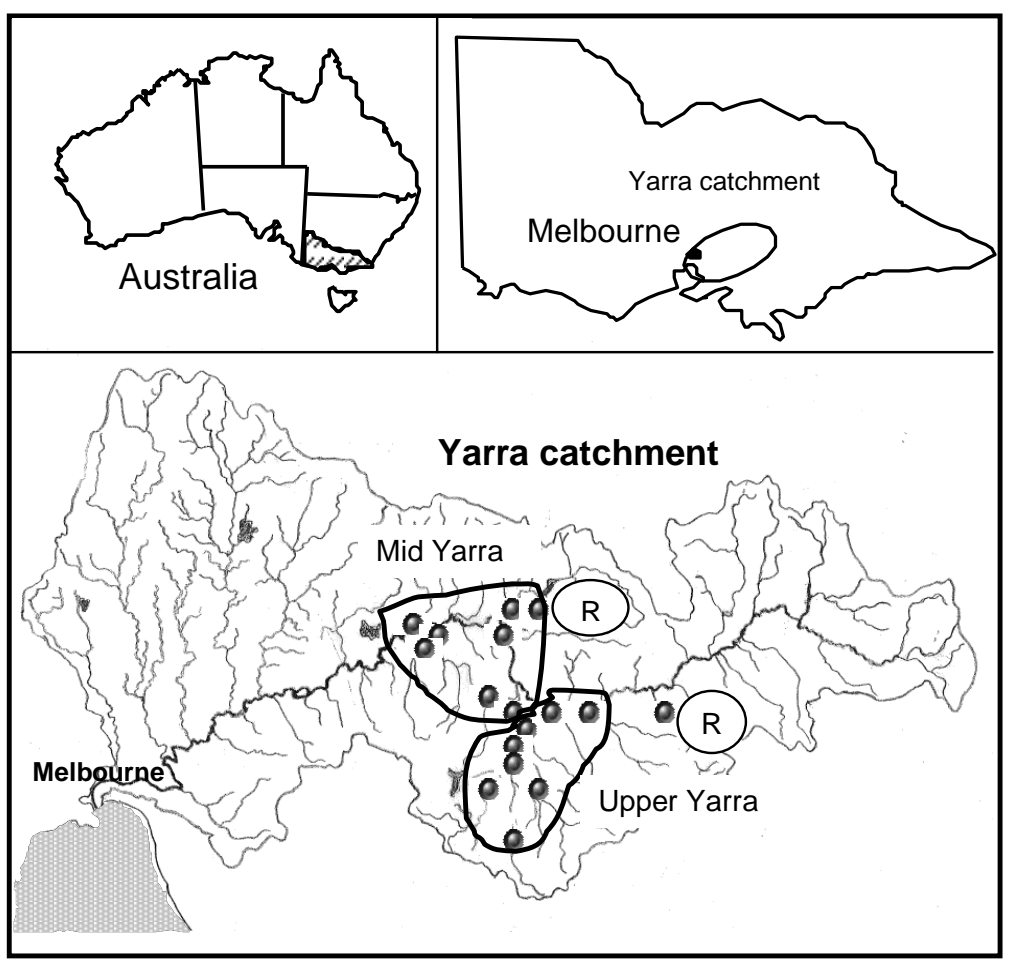

Figure 1 Schematic diagram illustrating the 18 monitoring sites (indicated by the circles) in the Yarra catchment, Victoria, Australia 
Study area

The Yarra catchment $\left(38^{\circ} \mathrm{S}, 145^{\circ} \mathrm{E}\right)$ is a large area $\left(\sim 7000 \mathrm{~km}^{2}\right)$ that extends approximately 150 $\mathrm{km}$ east/north-east from Melbourne, Victoria, Australia (Figure 1). The area has undulating terrain with elevation ranging from $50-400 \mathrm{~m}$. The soils on the northern side of the valley are grey to grey-brown loamy sands to clay loams whilst on the southern side red volcanic soils dominate. Across the catchment the soils are typically relatively acidic ( $\mathrm{pH} 5.5-6.0)$ with total organic carbon contents in the range of $2-5 \%$ (Wightwick et al. 2008). The mean annual maximum temperature is $\sim 20^{\circ} \mathrm{C}$ and the long-term annual rainfall is $700-1000 \mathrm{~mm}$ (BOM 2010).

Eighteen sites were investigated in this study, of which sixteen were in the Middle and Upper Yarra catchment area (Figure 1). The middle Yarra catchment (upstream of Yering Gorge) contains a variety of land uses, including residential, rural residential, industrial and a broad range of agricultural activities. According to Melbourne Water (2007) land use activities are production forestry $(33.4 \%)$, grazing modified pastures $(25.2 \%)$, rural residential $(9.3 \%)$ and National Parks (6.2\%). Horticulture production accounts for about $7 \%$ of the land use, which includes irrigated vine fruits $(2.7 \%)$, irrigated vegetable and herbs $(0.6 \%)$, irrigated tree fruits $(1.4 \%)$, irrigated seasonal horticulture $(1.3 \%)$, irrigated flowers and bulbs $(0.3 \%)$, and intensive horticulture $(0.8 \%)$. These horticultural production systems represent the land uses in the catchment which have historically relied on $\mathrm{Cu}$-based fungicide use. The catchment also includes small areas of intensive animal production (0.8\%). In addition, there are three major sewage treatment plants in the catchment that discharge in Olinda $\mathrm{Ck}$, the Watts River and the Yarra River downstream of Yarra Junction. Three sites were located on the Yarra River to reflect integrated impacts and six sites were located on the lower reaches of major tributaries. Eight sites were located in the Woori Yallock catchment where a wide variety of intensive agricultural activities operate. Two sites were reference sites located in forested water supply catchments that were closed to human access.

\section{Sediment sampling}

Sites were sampled in the spring (October 2008) via the collection of spot surface sediment samples. Spring is an important growing season for horticulture crops and represents a period of intensive fungicide use. For instance, in grapevines it is common practice to apply fortnightly preventative fungicide sprays during the growing season. Sediment samples were collected by using a dip net (360 $\mu \mathrm{m}$ mesh) to scoop surface sediments from the bottom of the stream/river 
bed. The sediment was then wet filtered on site through a $64 \mu \mathrm{m}$ mesh net into a bucket and left to settle for at least 10 minutes. To prevent cross contamination between sites the buckets and nets were thoroughly rinsed after collection and then again prior to collection at the next site prior to collection. Supernatant (water) was decanted off and the wet sediment transferred into $1 \mathrm{~L}$ solvent-rinsed glass jars. After further settling in the laboratory, the remaining supernatant was decanted off, the sediment dried $\left(40^{\circ} \mathrm{C}\right)$, and ground to $<1 \mathrm{~mm}$. Water and sediment samples were kept on ice during transportation to the laboratories where they were stored at $4^{\circ} \mathrm{C}$ prior to further processing.

\section{Analysis of copper and other metals in sediments}

Sediment samples were analysed to determine total concentrations of $\mathrm{Cu}$ and other metals $(\mathrm{Cd}$, $\mathrm{Co}, \mathrm{Cr}, \mathrm{Ni}, \mathrm{Pb}$ and $\mathrm{Zn}$ ) that are of concern for aquatic ecosystems (ANZECC and ARMCANZ 2000). Sediment samples were extracted using the microwave assisted reverse aqua-regia $\left(3 \mathrm{HNO}_{3}: 1 \mathrm{HCl}\right)$ method (Wightwick et al. 2010b). Total concentration (mg/kg; dry weight (d.w.)) of metals in sediment samples were quantified by inductively coupled plasma mass spectrometry (ICP-MS; Ultramass ICP-MS, Varian, Mulgrave, Australia). Each of two standard reference soils was processed in duplicate. One of the standard reference soils (ISE 990) was from the Wageningen Evaluating Programs for Analytical Laboratories (WEPAL) (Wageningen University, Netherlands) whilst the other was an internal reference soil used in our laboratory (SCL 1000-6). Recoveries from the standard reference soils were, for the most part between 85 and $105 \%$ of the stated values. In some instances lower recoveries $(74-83 \%)$ were obtained for $\mathrm{Cr}, \mathrm{Co}, \mathrm{Ni}, \mathrm{Cu}$ and $\mathrm{Zn}$ for ISE 990. Two randomly selected samples were processed in duplicate with CV\% of the duplicate readings for the most part being $<10 \%$, and no greater than $15 \%$. The method Limit of Reporting (LOR) for all elements was $0.4 \mathrm{mg} / \mathrm{kg}$.

\section{Results and Discussion}

Copper-based fungicides have been used for many years on horticultural properties within the study catchment, particularly in vineyards and orchards, and this use is likely to have resulted in considerable accumulation of $\mathrm{Cu}$ in surface soils (as has been reported in vineyards within southern Australia; Wightwick et al. 2008). For example, Wightwick et al. (2008) estimated that over the past $20-40$ years, $58-700 \mathrm{~kg} / \mathrm{ha}$ of $\mathrm{Cu}$ has been applied to vineyards in the catchment resulting in accumulated $\mathrm{Cu}$ concentrations in surface soils of up to $223 \mathrm{mg} / \mathrm{kg}$ (mean $87 \mathrm{mg} / \mathrm{kg}$ ). 
Table 1 Concentration of metals detected in sediment samples

\begin{tabular}{ccccccccc}
\hline \multirow{2}{*}{ Metal } & \multicolumn{3}{c}{ Study Sites (n = 16) } & \multicolumn{2}{c}{ Reference sites (n = 2) } & \multicolumn{2}{c}{ ISQG $^{\text {a }}$} \\
\cline { 2 - 9 } & Mean & 95\% CI & Max & Mean & 95\% CI & Max & Low & High \\
\hline & & & & \multicolumn{2}{c}{ mg/kg (dry weight) } \\
$\mathrm{Cd}$ & $<0.4$ & - & $<0.40$ & $<0.4$ & - & $<0.4$ & 1.5 & 10 \\
$\mathrm{Cr}$ & 24.0 & $21.1-26.7$ & 32.0 & 23.0 & $14.8-32.2$ & 28.0 & 80 & 370 \\
$\mathrm{Co}$ & 7.0 & $6.47-8.33$ & 10.0 & 8.0 & $5.4-10.4$ & 9.0 & $\mathrm{ND}$ & $\mathrm{ND}$ \\
$\mathrm{Cu}$ & 12.0 & $10.6-13.6$ & 17.0 & 12.0 & $6.7-16.8$ & 14.0 & 65 & 270 \\
$\mathrm{Ni}$ & 11.0 & $9.25-12.1$ & 15.0 & 10.0 & $5.4-15.0$ & 12.0 & 21 & 52 \\
$\mathrm{~Pb}$ & 17.0 & $11.6-23.2$ & 60.0 & 16.0 & $12.4-19.5$ & 18.0 & 50 & 220 \\
$\mathrm{Zn}$ & 67.0 & $52.5-81.4$ & 121 & 57.0 & $31.7-81.7$ & 69.0 & 200 & 410 \\
\hline
\end{tabular}

ISQG Interim Sediment Quality Guideline Value; ${ }^{a}$ Values from, Australian and New Zealand Guidelines for Fresh and Marine Water Quality (ANZECC and ARMCANZ 2000); CI, confidence interval; ND, not determined.

The accumulation of $\mathrm{Cu}$ in surface soils of farms may pose a risk to nearby surface waters if it is transported off-site due to run-off (Fernández-Calviño et al. 2008; Ribolzi et al. 2002). However, in this study it was found that the concentrations of $\mathrm{Cu}$ in the sediment samples sites were similar to the concentrations present in the samples from the reference sites (Table 1). Mean observed $\mathrm{Cu}$ concentrations at study sites were consistent with median concentrations reported by Bereswell et al. (2012) in streams associated with German vineyards ( $32 \mathrm{mg} / \mathrm{kg}$ d.w.), albeit that in this study the range observed $(10.6-13.6 \mathrm{mg} / \mathrm{kg} \mathrm{d} . \mathrm{w})$ was much less variable and very much at the lower end of the range reported by Bereswell et al. (range 7.3-117 mg/kg d.w.). Furthermore, concentrations of almost all measured metals (including $\mathrm{Cu}$ ) in the sediments were below the interim sediment quality guideline values listed in the Australian water quality monitoring guidelines (ANZECC and ARMCANZ 2000; Table 1). The one exception was $\mathrm{Pb}(60 \mathrm{mg} / \mathrm{kg}$ d.w.), which exceeded the low $(50 \mathrm{mg} / \mathrm{kg})$ but not the high $(220 \mathrm{mg} / \mathrm{kg})$ sediment quality guideline value at one of the study sites (Table 1). Copper, $\mathrm{Pb}$ and $\mathrm{Zn}$ concentrations were generally lower than those reported by Marshall et al. (2010) in samples collected from the nearby, but more heavily urbanised catchment, Dandenong Creek $(\mathrm{Cu}, 7.0$ - 59 mg/kg d.w.; Pb, 12 - $75 \mathrm{mg} / \mathrm{kg}$ d.w.; Zn, 52 - $890 \mathrm{mg} / \mathrm{kg}$ d.w.). Overall, whilst there was no evidence of $\mathrm{Cu}$ accumulation in the sediments at the study sites, the broader study (Schäfer et al. 2011; Wightwick et al. 2012) did identify the presence of synthetic fungicide compounds in the same sediments, indicating that some agricultural chemicals are migrating from agricultural land towards surface waterways in the catchment.

Sediments are known long-term sources of secondary metal contamination for aquatic organisms due to their capacity to sequester and subsequently release metals (Luoma and Rainbow 2008). 
Eleven of the study sites are used by the local water authority (Melbourne Water) for drinking water quality monitoring, although, unfortunately, not the two reference sites. Monthly water samples collected by the authority from these sites are analysed for a range of chemicals, including for $\mathrm{Cu}$. Concentrations of $\mathrm{Cu}$ in 2008-09 in approximately $40 \%$ of the samples from the study sites (mean $2.8 \mu \mathrm{g} / \mathrm{L}, 95 \%$ C.I. 2.4-3.1 $\mu \mathrm{g} / \mathrm{L}$; Melbourne Water (2011) exceeded the Australian freshwater quality guideline for the protection of $95 \%$ of aquatic species $(1.4 \mu \mathrm{g} / \mathrm{L}$; ANZECC and ARMCANZ 2000), suggesting that $\mathrm{Cu}$ concentrations in the water column are high enough to pose an ecological risk to aquatic organisms.

\section{Conclusions}

Overall, the data on $\mathrm{Cu}$ and other metals in the sediments suggests that that there is unlikely to have been wide spread, diffuse, off-site transport of $\mathrm{Cu}$ from the soils of horticultural properties to nearby surface waterways in the Yarra catchment, and that observed sediment metal concentrations are unlikely to pose an ecological risk to sediment dwelling organisms at the study sites. It is possible that this is occurring at specific point sources in the catchment that were missed by the random sampling approach adopted in this study; further investigations would be needed to assess this (e.g. soil sampling to assess $\mathrm{Cu}$ accumulation at sites adjacent to surface waterways, sediment sampling to target likely point sources). The water quality data collected by the local water authority showed $\mathrm{Cu}$ concentrations in the water column to be high enough to pose an ecological risk to aquatic organisms. It is not possible to confirm that this latter observation is due to anthropogenic inputs of $\mathrm{Cu}$ to the waterways or to elucidate whether horticultural activities were a significant source of anthropogenic inputs of $\mathrm{Cu}$. This represents a significant research gap, as many aquatic organisms are likely to be sensitive to copper-based fungicides, and further, integrated biological, ecological and chemical investigations in this economically and socially important Victorian catchment are required.

\section{Acknowledgements}

This study was supported by Melbourne Water, the Department of Primary Industries Victoria, Australia (DPI) Future Farming Systems Research Key Project FF104 Accountable Agriculture (Project 103371, 100704, 104049), the Co-operative Research Centre for Contamination Assessment and Remediation of the Environment (CRC CARE) and The Centre for Aquatic Pollution, Identification and Management (CAPIM). CAPIM is funded by The Victorian Science 
Agenda Investment Fund managed by the Department of Business and Innovation (DBI) (www.innovation.vic.gov.au) with partner funding contributed from Melbourne Water, Department of Primary Industries (Victoria), and Environment Protection Authority (Victoria). We also acknowledge Steve Marshall and other staff from University of Melbourne for their help with field sampling.

\section{References}

Allinson, G., Laurenson, L.J.B., Pistone, G., Stagnitti, F., Jones, P.L. (2000). Effect of dietary copper on the crayfish, Cherax destructor. Ecotoxicology and Environmental Safety, 46,117123.

ANZECC and ARMCANZ, 2000. Australian and New Zealand guidelines for fresh and marine water quality. Australian and New Zealand Environment and Conservation Council/Agriculture and Resource Management Council of Australia and New Zealand, Canberra, ACT.

Bereswill, R., Golla, B., Streloke, M., Schulz, R. (2012). Entry and toxicity of organic pesticides and copper in vineyard streams: Erosion rills jeopardise the efficiency of riparian buffer strips. Agriculture Ecosystems and Environment, 146, 81-92.

BOM (2010) Climate data online. Bureau of Meteorology, Commonwealth of Australia. http://www.bom.gov.au/climate/. Accessed June 2010.

Diaz-Ravina, M., de Anta, R.C., Baath, E. (2007). Tolerance (PICT) of the bacterial communities to copper in vineyards soils from Spain. Journal of Environmental Quality, 36, 1760-1764.

Fernández-Calviño, D., Rodríguez-Suárez, J.A., López-Periago, E., Arias-Estévez, M., SimalGándara, J. (2008). Copper content of soils and river sediments in a winegrowing area, and its distribution among soil or sediment components. Geoderma, 145, 91-97.

Fernández-Calviño, D., Soler-Rovira, P., Polo, A., Díaz-Raviña, M., Arias-Estévez, M., Plaza, C. (2010). Enzyme activities in vineyard soils long-term treated with copper-based fungicides. Soil Biology and Biochemistry, 42, 2119-2127.

Komárek, M., Cadková, E., Chrastný, V., Bordas, F., Bollinger, J.-C. (2010). Contamination of vineyard soils with fungicides: A review of environmental and toxicological aspects. Environment International, 36, 138-151.

Luoma, S.L., Rainbow, P.S. (2008). Metal contamination in aquatic environments: science and lateral management. Cambridge University Press, Cambridge, UK.

Marshall, S., Pettigrove, V., Carew, M., Hoffmann, A. (2010). Isolating the impact of sediment toxicity in urban streams. Environmental Pollution, 158, 1716-1725.

Melbourne Water (2007). Drinking water quality risks in Melbourne's open water supply catchments: development of a risk quantification. Final Report. Melbourne Water, Melbourne Australia.

Melbourne Water (2011). Melbourne Water long term water quality monitoring database. (Melbourne Water, Victoria, Australia).

Ranjard, L., Echairi, A., Nowak, V., Lejon, D.P.H., Nouaim, R., Chaussod, R. (2006). Field and microcosm experiments to evaluate the effects of agricultural $\mathrm{Cu}$ treatment on the density and 
genetic structure of microbial communities in two different soils. Fems Microbiology Ecology, 58, 303-315.

Ribolzi, O., Valles, V., Gomez, L., Voltz, M. (2002). Speciation and origin of particulate copper in runoff water from a Mediterranean vineyard catchment. Environmental Pollution, 117, 261-271.Schäfer, R.B., Pettigrove., V, Rose, G., Allinson, G., Wightwick, A., von der Ohe, P.C., Shimeta, J., Kefford, B.J. (2011). Effects of 97 pesticides monitored with three sampling methods in 24 streams on macroinvertebrates and microorganisms. Environmental Science \& Technology. $45: 1665$ - 1672.

Wang, Q.-Y., Zhou, D.-M., Cang, L. (2009). Microbial and enzyme properties of apple orchard soil as affected by long-term application of copper fungicide. Soil Biology and Biochemistry, 41,1504 - 1509.

Wightwick, A., Mollah, M., Partington, D., Allinson, G. (2008). Copper fungicide residues in Australian vineyard soils. Journal of Agricultural and Food Chemistry, 56, 2457 - 2464.

Wightwick, A., Walters, R., Allinson, G., Reichman, S.M., Menzies, N.W. (2010a). Environmental risks of fungicides used in horticultural production systems. In O. Carisse (Ed.), Fungicides. pp. 273 - 304. InTech: Reijka, Croatia.

Wightwick, A.M., Croatto, G., Allinson, G., Menzies, N.W. (2010b). Use of Reference Soils in Determinations of $0.01 \mathrm{M}$ Calcium Chloride Available Metals. Communications in Soil Science and Plant Analysis, 41, 2602 - 2612.

Wightwick, A.M., Bui, A., Zhang, P., Rose, G., Allinson, M. Myers, J.H., Reichman, S.M., Menzies, N.W., Pettigrove, V., Allinson, G. (2012) Environmental fate of fungicides in surface waters of a horticultural production catchment in south-eastern Australia. Archives of Environmental Contamination and Toxicology, 62, $380-390$. 


\section{University Library}

\section{- M M N E R VA A gateway to Melbourne's research publications}

Minerva Access is the Institutional Repository of The University of Melbourne

\section{Author/s:}

Wightwick, AM;Croatto, G;Reichman, SM;Menzies, NW;Pettigrove, V;Allinson, G

Title:

Horticultural Use of Copper-Based Fungicides Has Not Increased Copper Concentrations in Sediments in the Mid- and Upper Yarra Valley

\section{Date:}

2013-12-01

\section{Citation:}

Wightwick, A. M., Croatto, G., Reichman, S. M., Menzies, N. W., Pettigrove, V. \& Allinson, G. (2013). Horticultural Use of Copper-Based Fungicides Has Not Increased Copper Concentrations in Sediments in the Mid-and Upper Yarra Valley. WATER AIR AND SOIL POLLUTION, 224 (12), https://doi.org/10.1007/s11270-013-1701-3.

Persistent Link:

http://hdl.handle.net/11343/283000 